Article

\title{
Meteorological Storm Influence on the Ionosphere Parameters
}

\author{
Olga Borchevkina 1,2,*(D), Ivan Karpov ${ }^{1,2}$ and Mikhail Karpov ${ }^{1,2} \mathbb{D}$ \\ 1 West Department of Pushkov Institute of Terrestrial Magnetism, Ionosphere and Radio Wave Propagation, \\ RAS, 236035 Moscow, Russia; ivkarpov@inbox.ru (I.K.); mikhailkarpov@hotmail.com (M.K.) \\ 2 Institute of Physics, Mathematics and IT, Immanuel Kant Baltic Federal University, Kaliningrad 236016, Russia \\ * Correspondence: olgaborchevkina@gmail.com; Tel.: +7-4012-215-606
}

Received: 1 September 2020; Accepted: 20 September 2020; Published: 22 September 2020

check for updates

\begin{abstract}
This paper presents the observations of ionospheric parameters in Kaliningrad $\left(54^{\circ} \mathrm{N}\right.$, $20^{\circ}$ E) during a meteorological storm in the Baltic Sea during October 2017 and 2018. Analysis of the total electronic content (TEC) during the storm showed that perturbations of the TEC values from the median can reach two standard deviations of the value. For the critical frequency of the F2 layer, it was 1.5-1.6 times the standard deviations. On days of a meteorological storm, significant changes were noted in the dynamics of the E-layer's critical frequency. The reasons for the occurrence of the observed phenomena were due to the propagation of acoustic-gravity waves generated by convective processes in the lower atmosphere during periods of a meteorological storm. Spectral analysis of TEC variations revealed an increase in the amplitudes of ionospheric variations 10-16 min over the area of a meteorological storm. The analysis allowed us to conclude that ionospheric perturbations during the meteorological perturbation were caused by increased acoustic-gravity wave (AGW) generation processes in the lower atmosphere. The most likely cause of negative ionospheric disturbances were processes associated with the dissipation of AGW propagating from the area of a meteorological storm and increased turbulence in the lower thermosphere.
\end{abstract}

Keywords: meteorology disturbances; acoustic gravity waves; atmosphere-ionosphere coupling; sporadic E layer; total electron content

\section{Introduction}

One of the important problems of atmospheric physics is the study of the processes determining the influence of the lower atmosphere dynamics on the variability of the parameters of the ionosphere. The most important factors that affect the state of the ionosphere are associated with solar and geomagnetic activity [1,2]. However, the influence of processes in the lower atmosphere on the state and dynamics of the upper atmosphere cannot be underestimated [3].

Experimental studies of the state and dynamics of the ionosphere over areas with extreme meteorological events, such as hurricanes and typhoons, demonstrate the formation of various kinds of effects, including traveling ionospheric disturbances (TIDs), electric field and total electron content (TEC) disturbances, occurrences of optical emissions, F-scattering phenomena, etc. Spatial scales up to several hundred kilometers and existence times from several hours to 1-2 days depend on the intensity, duration, and scale of the event [4-13]. Monitoring less intense events also shows their impact on the upper atmosphere, although the effects in these cases are less pronounced [11,14-16].

Such a variety of ionospheric disturbances significantly complicates the tasks of interpreting observations and developing physical ideas about the processes that determine the reaction of the upper atmosphere. Increasing geomagnetic and solar activity causes an additional difficulty $[1,2,17-20]$ and makes it impossible to reveal ionospheric effects from events associated with meteorological activity. 
The impact of such phenomena in the lower atmosphere on the ionosphere is carried out in two ways: (1) electrical and electromagnetic phenomena, such as thunderstorms, sprites, etc. [21,22]; (2) through the propagation of various types of waves (e.g., planetary waves, tides, gravity waves, infrasound, etc.) with periods from several seconds to several days [23-28].

Much attention has been paid to the study of the role of acoustic-gravity waves (AGW), which can propagate from the lower atmosphere to the heights of the thermosphere and, to a large extent, determine the reaction of the ionosphere. AGW is an energetically powerful source that affects the state of the neutral gas in the atmosphere and, as a consequence, the ionosphere, which is confirmed by experimental studies [29-31].

The sources of such waves in the lower atmosphere are diverse. For example, they include mesoscale turbulence and convection [32-35], mesoscale disturbances arising in the atmosphere when a stationary incoming stream flows around mountains (the so called orography effects) [36,37], earthquakes [38-40], the passage of the solar terminator and solar eclipse [41-45], meteorological disturbances, and typhoons [46-55]. In numerous theoretical studies, the generation, propagation, and influence of AGWs have been studied in sufficient detail [56-58].

So-called meteorological processes are associated with local (from several hundred to thousands of kilometers) and intense changes in weather conditions that last for several days. According to [5], the contribution from meteorological disturbances is about $15 \%$ of the total variability of the ionosphere. Moreover, [6] estimated that the meteorological contribution was about $15-35 \%$ under calm geomagnetic conditions.

When studying the meteorological influence on the ionosphere, the role of wave processes is considered as the primary cause. The passage of atmospheric fronts, the formation of mesoscale turbulence, jet streams, and other meteorological processes in the lower atmosphere, are sources of AGW generation. As AGW propagates from the surface source, their amplitude intensifies due to a decrease in density at higher altitudes. The conditions for wave propagation in the upper atmosphere are also characterized by a rapid rise in temperature associated with the intensification of dissipative processes. Dissipation processes largely determine the possibilities of vertical propagation of waves and the height to which an atmospheric wave can propagate. Theoretical studies show that meteorological sources excite relatively short-period AGW [59]. Infrasonic waves and AGW with periods close to the Brunt-Väisälä period, propagating from the excitation region almost vertically, can reach the heights of the thermosphere and ionosphere [60]. The dissipation of such waves leads to the formation of local heating of the upper thermosphere and increasing turbulent processes in the lower thermosphere, which, in turn, affects the dynamics, gas composition, and ionization-recombination processes of the ionosphere [61-65].

However, the results of theoretical studies are of a qualitative nature, since experimental data on the space-time variations of the parameters of the lower atmosphere under disturbed conditions are insufficient to describe the initial conditions and sources of AGW. As a result, it remains necessary to conduct more experimental studies of ionosphere response to disturbances in the lower atmosphere for a better understanding of which mechanisms and at what altitudes prevail during the energy transfer from the lower regions to the ionosphere.

The purpose of this work is to analyze the results of ionospheric observations carried out in the Kaliningrad region during the passage of two strong meteorological storms that occurred in October 2017 and October 2018 against the background of calm geomagnetic activity.

\section{Events Selection}

The southeastern Baltic region, where Kaliningrad is located, is opened to penetration of western transit air masses. According to the materials of long-term meteorological observations, the number of days with strong winds (>15 m/s) in the Kaliningrad region was 28-38 per year, and in some years up to 60 days. The autumn-winter period (November-January) accounted for up to half of the stormy 
days. The strength of the observed storms was usually $7-8$ points on the Beaufort scale $(12-18 \mathrm{~m} / \mathrm{s})$, occasionally 9-10 points (18-25 m/s), in exceptional cases the wind reached $11-12$ points $(>25 \mathrm{~m} / \mathrm{s})$.

The paper presents the analysis of disturbances in the parameters of the $\mathrm{E}$ and $\mathrm{F}$ regions of the ionosphere based on observations in Kaliningrad $\left(54^{\circ} \mathrm{N}, 20^{\circ} \mathrm{E}\right)$ during meteorological storms that occurred in October 2017 and 2018. To describe the meteorological situation, we used the measurements of the maximum values of wind gusts, as well as the atmospheric pressure reduced to mean sea level, according to Ref. [66]. Measurements of the meteorological station in Olsztyn (53 $\mathrm{N}, 20^{\circ} \mathrm{E}$ ), Poland (hourly measurements) were used as an additional data source. Variations in the ionosphere parameters were obtained from measurements by Parus-A ionosonde of the Kaliningrad branch of IZMIRAN.

A series of meteorological events with the maximum wind speed in Kaliningrad of $17 \mathrm{~m} / \mathrm{s}$ or more (corresponded to the Beaufort scale of 8 points or higher), which occurred during low geomagnetic and solar activity, were selected for the analysis. The criterion for quiet conditions was the Kp-index $\leq 3$ on the day of the event and on the previous day. Moreover, the Dst-index value was $-20 \leq \mathrm{Dst} \leq 20 \mathrm{nT}$ and did not change by more than $20 \mathrm{nT}$ during the day. Such a criterion for the selection of events minimizes the influence of geomagnetic factors on the state of the ionosphere and allows us to say that the observed ionospheric disturbances were mainly determined by meteorological processes.

Figure 1 shows the results of observations of the maximum values of wind gusts and atmospheric pressure, which were reduced to the mean sea level in Kaliningrad, obtained from the data of Ref. [66]. Further, variations were found in geomagnetic indices during the period of meteorological storms that occurred in October 2017 and 2018. As one can see, the analyzed events occurred during calm geomagnetic conditions. Meteorological storms reached their maximum development in 2017 till 07:00 UT on 29 October to 03:00 UT on 30 October; and in 2018 till 03:00 UT in 23 October to 18:00 UT in 24 October 2018, when ff3 reached 20 and $17-20 \mathrm{~m} / \mathrm{s}$, respectively.

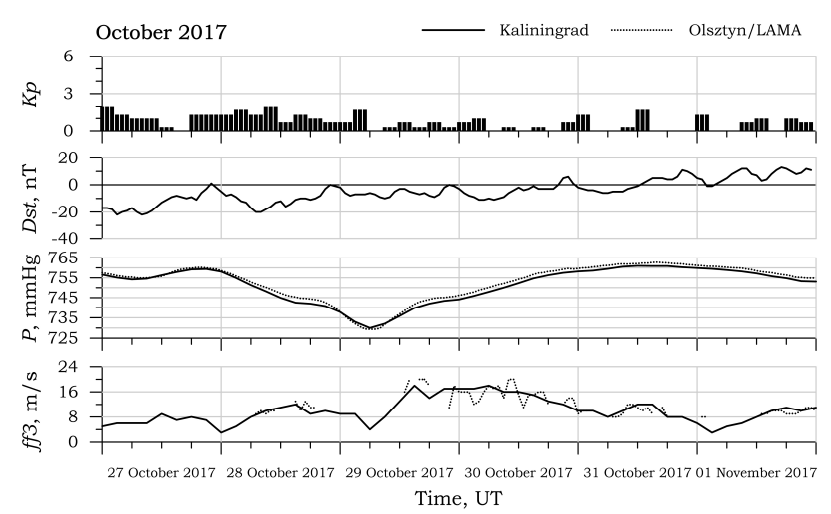

(a)

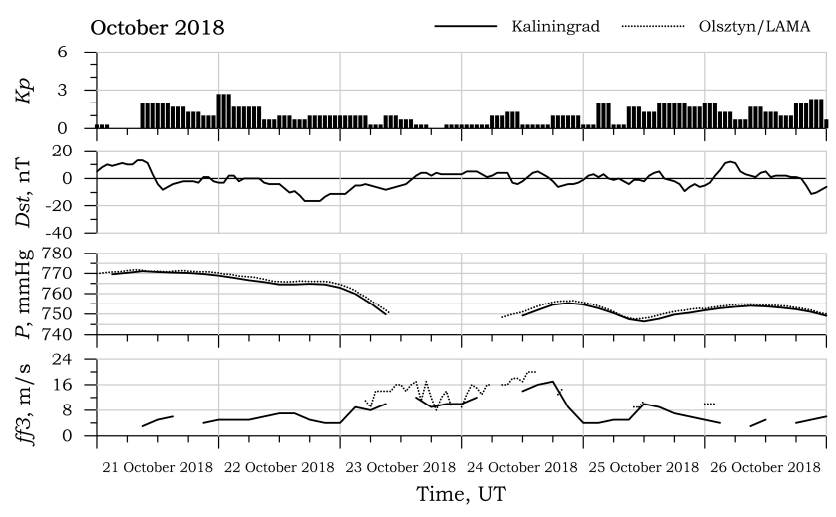

(b)

Figure 1. Variations in atmospheric pressure $\mathrm{P}$, maximum wind gusts $\mathrm{ff3}$, indices of geomagnetic activity Kp and Dst in Kaliningrad and Olsztyn during (a) 27 October-1 November 2017 and (b) 21-26 October 2018. 


\section{Influence of Meteorological Storm on E and F Regions of the Ionosphere}

As data for analyzing the response of the ionosphere, we used hourly measurements of the critical frequency of the F2-layer of the ionosphere (foF2), which characterizes the maximum in the vertical profile of the electron number density, according to the Parus-A ionosonde of the Kaliningrad branch of IZMIRAN. Moreover, the measurements of the TEC averaged over a 10-min interval according to GPS signal observation data. As an additional source of data, we used observations at the International GNSS (Global Navigation Satellite System) Service (IGS) station LAMA (Lamkowko, Poland, located near Kaliningrad).

To analyze the foF2 and TEC disturbances, we have estimated the deviations of these values at the i-th time moment relative to the moving median centered on the day of the considered day with a window of 13 days before and after the considered time moment:

$$
\begin{aligned}
\Delta x_{i} & =\frac{x_{i}-\bar{x}}{\bar{x}} \cdot 100 \%, \bar{x}=\frac{\sum_{i}^{N} x_{i}}{N}, \\
i & =-13 \ldots+13, N=27 .
\end{aligned}
$$

The standard deviation was determined as:

$$
\sigma=\sqrt{\frac{1}{N-1} \sum_{i}^{N}\left(x_{i}-\bar{x}\right)^{2}} .
$$

Figure 2a shows variations in the parameters of the ionosphere (total electron content and critical frequency of the F2 layer) from 27 October 2017 to 1 November 2017. The maximum wind gusts reached $20 \mathrm{~m} / \mathrm{s}$ in the second half of 29 October and the first half of 30 October. A significant increase in TEC was observed for several hours at night on 30 October 2017 (00:00-06:00 UT), reaching a maximum of $64 \%$ relative to the median values $(2 \sigma)$. In this time, the increase in foF 2 was $32 \%$ or 1.5 standard deviations. TEC and foF2 measurements on 21-26 October 2018 are shown in Figure $2 b$. By the middle of 23 October, the surface atmospheric pressure dropped below $750 \mathrm{mmHg}$. The wind speed exceeded $17 \mathrm{~m} / \mathrm{s}$ and reached $20 \mathrm{~m} / \mathrm{s}$ the next day. On the night of 24 October, an increase in the electron concentration was observed and by 06:00-12:00 UT the increase in TEC reached 20\% relative to the average values $(2.4 \sigma)$. The increase in the critical frequency of the F2 layer was $19 \%$ or $1.6 \sigma$ by 06:00-11:00 UT on 24 October 2018.

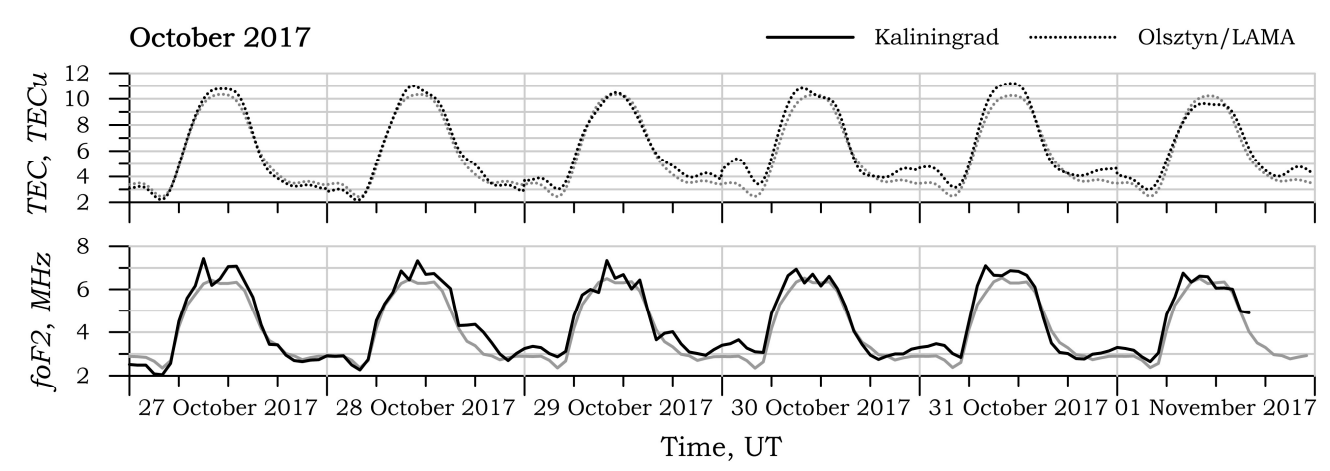

(a)

Figure 2. Cont. 


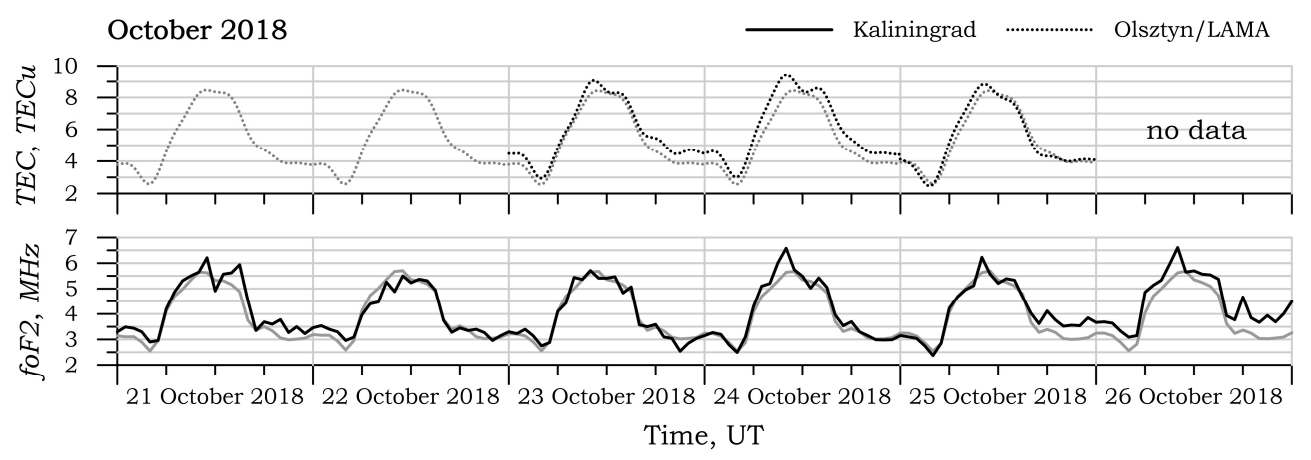

(b)

Figure 2. Total electronic content (TEC) and critical frequency of the F2 layer (foF2) measurements in Kaliningrad and Olsztyn (a) from 27 October to 1 November 2017; (b) 21-26 October 2018. The gray lines indicate the median values of TEC and foF2.

One can also note the time delay $(\sim 12 \mathrm{~h})$ between the appearance of the maximum wind disturbances in the lower atmosphere and the changes in the critical frequencies, as well as TEC, over the area of the meteorological storm. It is possible that the time delay in the appearance of ionospheric disturbances is determined by the wave nature of the processes that determine the connections between the lower and upper atmosphere. The effects of the meteorological storm in the ionosphere of the F region are more often manifested in the morning and daytime. In Ref. [67], it was shown that AGW had a weaker effect on the ionosphere parameters at night due to the lack of ionization sources and local scale of compensation sources. Furthermore, theoretical estimates of the influence of night sources on the ionosphere are shown in Ref. [68].

The development of a meteorological storm-accompanied by rapid changes in wind speed and leads to local ionospheric disturbances-manifested in an increase in daytime ionospheric TEC values directly above the meteorological disturbance region. The change in wind speed was determined by the unstable state of the atmosphere and characterized the processes of excitation of atmospheric waves.

The physical mechanisms of such behavior in the F-region ionosphere and their relative importance are well-known $[69,70]$. It can be assumed that the reasons for such ionospheric effects may be associated with the processes of horizontal plasma transfer from the region of a large-scale thermospheric disturbance that formed above the epicenter of a meteorological storm located north of Kaliningrad. For example, in the observations presented in $[15,16]$, it was shown that positive ionospheric effects occur at the southern border of the zone of meteorological disturbances.

Figure 3 shows the variations in the critical frequency (foEs, $\mathrm{MHz}$ ), including the minimum effective wake height Es ( $\mathrm{h}^{\prime} \mathrm{Es}, \mathrm{km}$ ) during the passage of meteorological storms in October 2017 and 2018, when the maximum wind speed in Kaliningrad exceeded $17 \mathrm{~m} / \mathrm{s}$.

During the passage of meteorological disturbances (29-30 October 2017 and 23 October 2018), a change in the characteristics of the sporadic Es layer was observed. It manifested itself in a decrease in the critical frequency foEs below the ionosonde sensitivity threshold $(\sim 2 \mathrm{MHz})$ and in a non-monotonic change in layer height.

In October 2017, the meteorological storm began at 06 UT on 29 October and lasted until 23:00 UT (Figure 3a). A rapid decrease in the critical frequency Es of the layer was noted after 12:00 UT. From 17:00 UT on 29 October till 06:00 UT on 30 October and from 14:00 UT on 30 October till 07:00 UT on 31 October, the critical frequency foEs decreased below the ionosonde sensitivity threshold ( $\sim 2 \mathrm{MHz})$.

In October 2018, the area of low atmospheric pressure in Kaliningrad was recorded from 06:00 to 23:00 UT on 23 October. The disappearance of the sporadic layer during this period was noted from 14:00 UT on 23 October till 07:00 UT on 24 October. After the passage of meteorological storms, the observed Es parameters recovered to pre-storm values. 


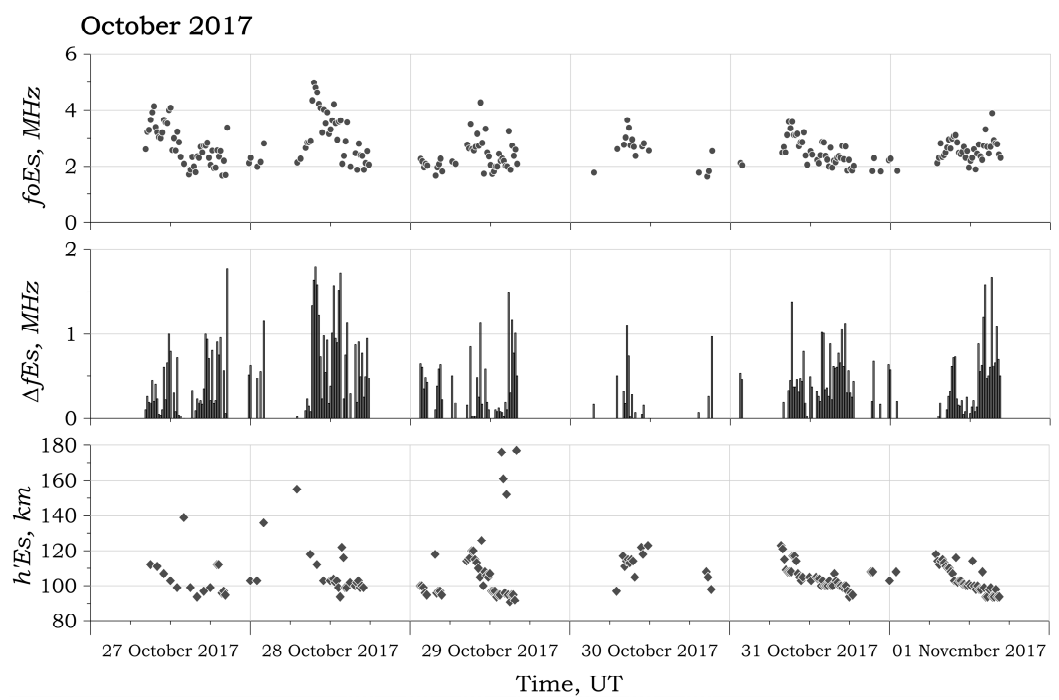

(a)

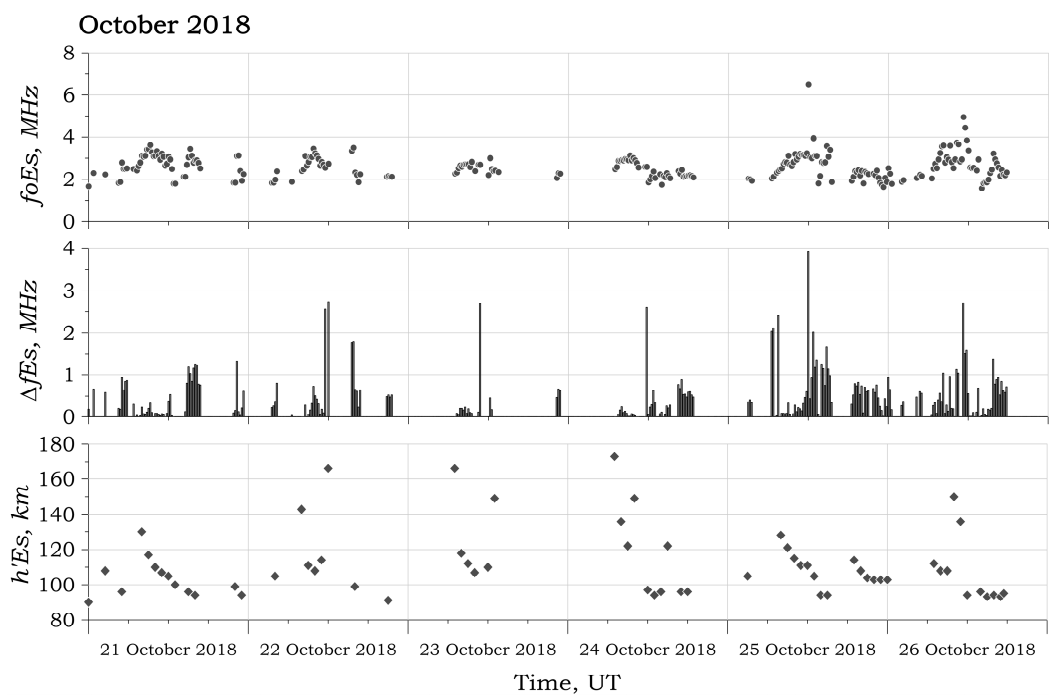

(b)

Figure 3. Time variations of the critical frequency foEs, the translucency range $\Delta \mathrm{fEs}$, and the minimum height h'Es of the sporadic Es layer on (a) 27 October-1 November 2017 and (b) 21-29 October 2018 according to vertical sounding data in Kaliningrad.

A significant decrease in the critical frequency and, accordingly, in the electron concentration of the E-layer, which was observed directly during a meteorological storm and was absent before and after the event under study, allowed one to associate such disturbances in the parameters of the lower ionosphere with processes caused by the passage of a meteorological storm.

According to theoretical concepts, the formation of sporadic layers in the E region of the ionosphere at mid-latitudes was due to the heterogeneity of the vertical structure of horizontal winds [71-74]. Despite the sporadic nature of the appearance of Es, regularities in the dynamics of its parameters made it possible to speak about the regularity of these variations. Presented observations of Es (Figure 3) clearly show the night layers caused by metal ions, as well as the morning increase in the height and critical frequency of the sporadic layer on the days preceding the passage of meteorological disturbances. During the days of a meteorological storm (29-30 October 2017), significant changes in the dynamics of the parameters of the sporadic layer appeared. The sporadic layer during these periods was observed only in the daytime. After the storm in the Kaliningrad region, the parameters of the sporadic layer recovered to the values observed on the days preceding the meteorological disturbances. 
Similar changes in the parameters of the sporadic layer were observed during the periods of the passage of summer thunderstorm fronts in Europe in 2013-2014 [75]. In these studies, it was shown that several hours after the thunderstorm fronts have passed through the observation area, the critical frequency Es dropped below the sensitivity threshold of the ionosondes ( 2 MHz). After analyzing the observation results, we came to the conclusion that the most probable cause of the Es layer disturbance is AGW generated in the troposphere and mesosphere during the passage of thunderstorm fronts [75].

Observations of disturbances of atmospheric and ionospheric parameters in the Kaliningrad region (Figures 2 and 3) also showed that the delay between the reaction of the ionosphere and the moment of maximum disturbances of atmospheric parameters was several hours. The delay was consistent with the concept of disturbances of the ionosphere initiated by AGWs of tropospheric origin. The results of observations presented in the paper were obtained under conditions of meteorological storms that took place in autumn without an increase in thunderstorm activity, which suggested that the main process of AGW generation was convective processes in the troposphere.

Numerous experimental and theoretical works have been devoted to studying the effect of AGW on sporadic layers in the E-region of the ionosphere $[59,63,64,71,76-81]$. These studies have considered various aspects of AGW influence, including the effect of waves on the inhomogeneity of horizontal winds at the heights of the E-region of the ionosphere, on the perturbation of the critical frequency of the layer, and on the recombination processes in the upper mesosphere and lower thermosphere.

Small time delays in the reaction of the ionosphere to disturbances in the troposphere made it possible to limit the spectral range of AGWs excited in the atmosphere and penetrating the heights of the ionosphere. Further, [59] showed that, under conditions of meteorological disturbances, AGWs are excited with short periods, which when propagating vertically, can reach the heights of the ionosphere in 2-3 $\mathrm{h}[61,82]$. Similar conclusions follow from the works [83-85], where it was shown that waves with periods close to the Brunt-Väisälä period are capable of propagating almost vertically and reaching the heights of the ionosphere. The effects of such waves are manifested in processes caused by wave dissipation and atmospheric turbulization at heights of the mesosphere and lower thermosphere. However, due to the smallness of the periods of such waves, the height, at which the effects of dissipation are noticeable, is significantly higher than the height of the E-layer of the ionosphere. Thus, it can be assumed that the effects of dissipation of such waves does not significantly affect Es dynamics. On the other hand, the vertical propagation of such waves and the growth of the amplitude with the height can lead to the breaking of waves at the heights of the lower thermosphere, which, presumably, leads to an increase in the atmospheric density at heights of the lower thermosphere and an increase in the intensity of recombination processes [86], which has a significant effect on turbulent processes $[87,88]$.

\section{Spectral Analysis}

Based on the theoretical studies $[59,61,83]$ and observational data $[7,15,16,30,48]$ presented above, it is clear that the observed changes in TEC values during meteorological storms were caused by the local heating of the thermosphere due to dissipation of AGWs propagating to the upper atmosphere from the region of meteorological disturbances in the lower atmosphere.

For further confirmation of this statement, it is important to show the increase of fluctuations with corresponding wave periods during the passages of meteorological storms over the observation stations, based on the spectral analysis of disturbances.

For experimental studies of the ionosphere, methods based on the receiving, processing, and interpretation of signals from satellites of global navigation systems (i.e., GPS and GLONASS) are widely used $[89,90]$.

The orbital periods of GPS satellites are practically equal to one day, which makes it possible to analyze the local daily changes in TEC by observing signals between passing satellites and ground stations located in a given region. The duration of observations of satellite signals passing in the field 
of visibility of the ground station reached 90 min or more, which was more than enough to detect variations with AGW periods.

To isolate the high-frequency components of the TEC variations, the spectrum of variations of the differential TEC was considered and defined as the ratio of the difference between TEC values on the satellite-station path of the receiving signals received in two successive time step observations. To determine the dynamics of the spectra during the observation period, the Wavelet transform was applied using the Morlet wavelet transform as the kernel.

The algorithm for collecting and processing observational data to determine the frequency characteristics of TEC variations included the following key points: (1) selecting satellites passing through the area of meteorological disturbance; (2) collecting data on TEC variations, time of flight of the satellite, and its trajectory; and (3) calculating the TEC wavelet spectrogram during the observation period of the satellite.

To study the frequency characteristics of TEC variations during meteorological storms that occurred in October 2017 and 2018, we considered observations at the mid-latitude station VIS0 (57 $\left.{ }^{\circ} \mathrm{N}, 18^{\circ} \mathrm{E}\right)$, located on the island of Gotland in the Baltic Sea, directly in the area of meteorological disturbances.

In the analysis of the observations of signals from individual GPS satellites, TEC variations were distinguished with periods of no more than $30 \mathrm{~min}$, which corresponded to the periods of AGW and IGW, which, as shown above, propagated almost vertically from the meteorological storm area to the heights of the upper atmosphere. Figure 4 shows the trajectory of the PRN3 satellite over the VIS0 station on the latitude-longitude map of surface pressure on 24 October 2018, according to the ERA5 reanalysis data [91]. The threshold value of the elevation angle for the analysis of the ionospheric response was determined to be no more than $30^{\circ}$. The satellite flyby was chosen as close as possible to the VIS0 receiving station. As can be seen from the figure, on 24 October 2018, the area of reduced pressure was located to the north of Kaliningrad.

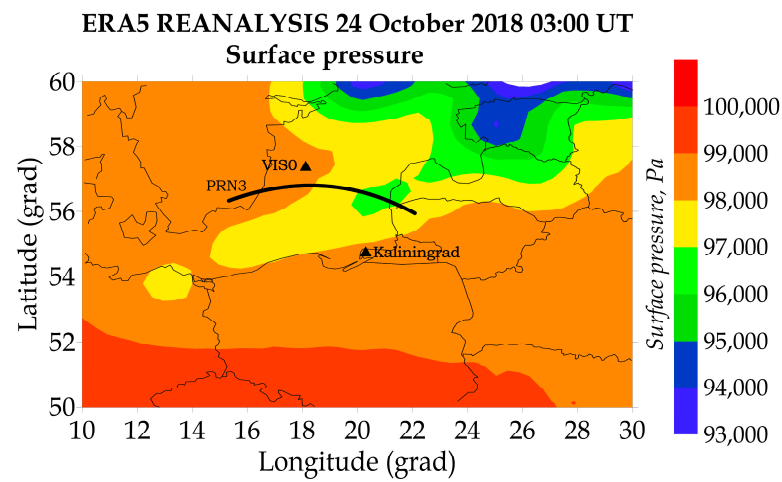

Figure 4. Surface pressure maps from ERA5 reanalysis data at 03:00 UT on 24 October 2018 and the trajectory of the PRN3 satellite.

Figure 5 shows the wavelet periodograms of the TEC variations over the VIS0 station from 27 October-1 November 2017 and 21-26 October 2018, which were obtained from the PRN 3 satellite signal observations. To calculate the wavelet periodograms of the TEC variations, the day-to-day data from a single GPS satellite was used to demonstrate the variability of AGW activity in the ionosphere during periods of meteorological activity. The GPS satellites orbited in an almost circular way, which allowed us to consider changes in spectral characteristics at the same time on different days. This consideration made it possible to exclude the influence of the regular sources on the ionosphere. The satellite flyby was recorded in the daytime (about noon), which allowed us to eliminate the effects of the solar terminator on the Earth's ionosphere. There were a large number of AGW sources in the lower atmosphere, so the presence of such waves was observed daily. However, as follows from Figure 5, during the periods of meteorological disturbances on 29-30 October 2017 and 23-24 October 2018, there was an increase in the intensity of variation with periods of 10-16 min. 
The variability of the wind speed in the lower atmosphere characterized the atmosphere dynamics instability and, consequently, the increase in wave activity. As already noted, in conditions of meteorological disturbances, an increase in wave activity in the AGW range was observed [92-94]. In observations of the frequency characteristics of TEC variations over VIS0 station, there was a significant increase in the amplitudes of harmonics with periods of 10-16 $\mathrm{min}$ and a maximum on the day of a meteorological storm (30 October 2017 and 23-24 October 2018). The storm was consistent with the position of the low-pressure region in the surface atmosphere (Figure 2) and with disturbances observed in the $\mathrm{E}$ and $\mathrm{F}$ regions of the ionosphere, which are presented in Section 3.

In theoretical studies, it was shown that the propagation of such waves from the Earth's surface and their dissipation in the upper atmosphere led to the formation of localized regions of thermosphere heating $[67,95,96]$. The appearance of increased temperature affected the ionization-recombination processes and led to the decrease of electron concentration directly above the epicenter of the meteorological disturbance.

Thus, under conditions of meteorological storms, the processes of AGW excitation in the lower atmosphere were enhanced. The propagation of such waves into the upper atmosphere led to the formation of disturbances in the state of the thermosphere on spatial scales determined by the duration and spatial dimensions of the region located in the zone of meteorological disturbance. The appearance of such areas affected the circulation and electrodynamic processes in the upper atmosphere and led to the local ionospheric disturbances over the storm area.
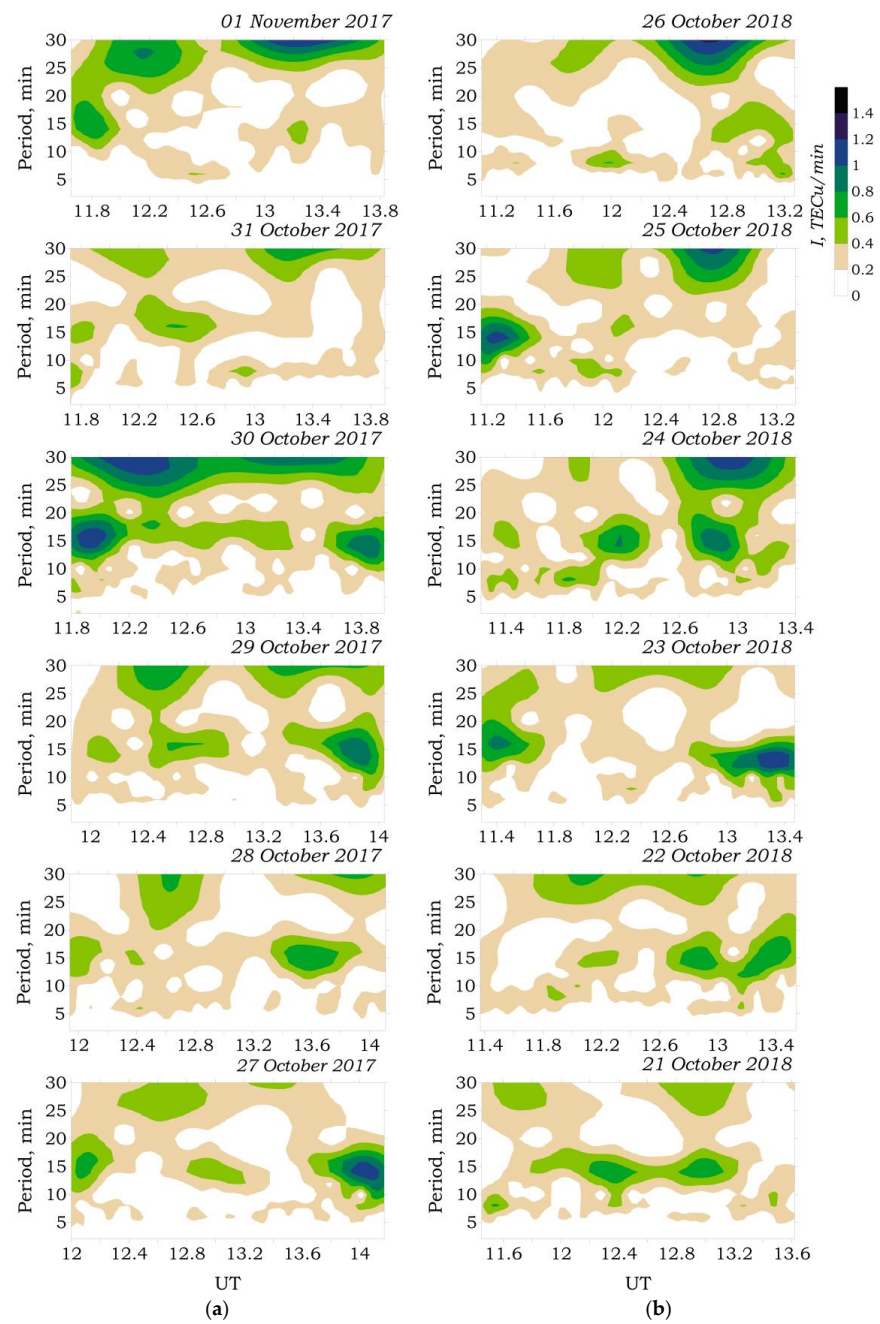

Figure 5. Wavelet spectrogram of AGWs associated with the convective storm system on October 2017 (a) and October 2018 (b) over VIS0 station $\left(57^{\circ} 48^{\prime} \mathrm{N}, 18^{\circ} 37^{\prime} \mathrm{E}\right)$ on Baltic sea. 


\section{Conclusions}

The parameters of two meteorological storms in the Baltic Sea that occurred on October 2017 and 2018 during calm geomagnetic events were analyzed. The results of a comprehensive experimental study showed:

1. The passage of meteorological storms had a significant impact on the ionospheric parameters of TEC and foF2. An increase in TEC was observed for several hours at night on 30 October 2017, reaching a maximum of $64 \%$ relative to the median values. Further, the increase in foF 2 was $32 \%$ during this time. The increase in TEC reached $20 \%$ relative to the median values. The increase in the critical frequency of the F2 layer was 19\% on the morning of 24 October 2018.

2. Results of observations of the sporadic Es layer dynamics in the Kaliningrad region during the passage of two meteorological storms in October 2017 and 2018 showed that under conditions of sufficiently strong meteorological disturbances. When the speed of wind gusts reached 8 points on the Beaufort scale and higher, there was a significant decrease in the critical frequency of the sporadic layer Es below the sensitivity threshold of the ionosonde. The observed phenomena at heights of the E region were apparently caused by the propagation of AGWs generated by convective processes in the lower atmosphere during periods of a meteorological storm. The effect of AGW was manifested in the intensification of turbulent processes in the lower thermosphere and, as a consequence, led to an increase in the density of the lower thermosphere and an increase in the efficiency of recombination processes.

3. Spectral analysis of TEC variations that occurred on from 27 October 2017 to 1 November 2017 and from 21 October to 26 October 2018 showed an increase in the amplitudes of variations with AGW periods of 10-16 min per day of a meteorological storm (29-30 October 2017 and 23-24 October 2018). Such waves can propagate almost vertically from the disturbance region in the lower atmosphere and reach the heights of the ionosphere and have a significant effect on the parameters of the ionosphere. The dynamics of changes in the region of such ionospheric variations is quite consistent with the change in the position of the low-pressure region.

The results of the analysis of atmospheric and ionospheric observations suggest that, under conditions of meteorological storms, the processes of AGW excitation in the lower atmosphere intensify. AGWs propagate vertically to the heights of the ionosphere and affect the turbulent regime of the lower thermosphere, which in turn leads to an increase in recombination processes and to the observed changes in the parameters of the ionosphere.

Author Contributions: O.B. and M.K. analyzed the data; I.K., O.B., and M.K. wrote the paper. All authors have read and agreed to the published version of the manuscript.

Funding: This research was funded by the Russian Foundation for Basic Research (project no. 18-05-00184 a).

Acknowledgments: We would like to express gratitude to the Copernicus Atmosphere Monitoring Service for the meteorology data; the International GNSS Service for access to GNSS data used in this study; and the OMNIWeb Plus NASA/Goddard Space Flight Center service for the data on geomagnetic and solar flux indices.

Conflicts of Interest: The authors declare no conflict of interest.

\section{References}

1. Mannucci, A.J.; Tsurutani, B.T.; Iijima, B.A.; Komjathy, A.; Saito, A.; Gonzalez, W.D.; Guarnieri, F.L.; Kozyra, J.U.; Skoug, R. Dayside global ionospheric response to the major interplanetary events of October 29-30 2003 "Halloween Storms". Geophys. Res. Lett. 2005, 32, L12S02. [CrossRef]

2. Yue, X.; Wang, W.; Lei, J.; Burns, A.; Zhang, Y.; Wan, W.; Liu, L.; Hu, L.; Zhao, B.; Schreiner, W.S. Long-lasting negative ionospheric storm effects in low and middle latitudes during the recovery phase of the 17 March 2013 geomagnetic storm. J. Geophys. Res. Space Phys. 2016, 121, 9234-9249. [CrossRef]

3. Forbes, J.M.; Maute, A.; Zhang, X.; Hagan, M.E. Oscillation of the ionosphere at planetary-wave periods. J. Geophys. Res. Space Phys. 2018, 123, 7634-7649. [CrossRef] 
4. Martinis, C.R.; Manzano, J.R. The influence of active meteorological systems on the ionosphere F region. Ann. Geofis. 1999, 1, 1-7. [CrossRef]

5. Isaev, N.V.; Kostin, V.M.; Belyaev, G.G.; Ovcharenko, O.Y.; Trushkina, E.P. Disturbances of the topside ionosphere caused by typhoons. Geomagn. Aeron. 2010, 50, 243-255. [CrossRef]

6. Isaev, N.V.; Sorokin, V.M.; Chmyrev, V.M.; Serebryakova, O.N.; Yashchenko, A.K. Disturbance of the electric field in the ionosphere by sea storms and typhoons. Cosm. Res. 2002, 40, 547-553. [CrossRef]

7. Polyakova, A.S.; Perevalova, N.P. Comparative analysis of TEC disturbances over tropical cyclone zones in the north-west Pacific Ocean. Adv. Space Res. 2013, 52, 1416-1426. [CrossRef]

8. Chernigovskaya, M.A.; Shpynev, B.G.; Ratovsky, K.G. Meteorological effects of ionospheric disturbances from vertical radio sounding data. J. Atmos. Sol.-Terr. Phys. 2015, 136, 235-243. [CrossRef]

9. Chou, M.Y.; Lin, C.C.H.; Yue, J.; Tsai, H.F.; Sun, Y.Y.; Liu, J.Y.; Chen, C.H. Concentric traveling ionosphere disturbances triggered by Super Typhoon Meranti (2016). Geoph. Res. Lett. 2017, 44, 1219-1226. [CrossRef]

10. Li, W.; Yue, J.; Yang, Y.; Li, Z.; Guo, J.; Pan, Y.; Zhang, K. Analysis of ionospheric disturbances associated with powerful cyclones in East Asia and North America. J. Atmos. Sol.-Terr. Phys. 2017, 161, 43-54. [CrossRef]

11. Borchevkina, O.P.; Karpov, I.V. Ionospheric irregularities in periods of meteorological disturbances. Geomagn. Aeron. 2017, 57, 624-629. [CrossRef]

12. Zakharov, V.I.; Kunitsyn, V.E. Regional features of atmospheric manifestations of tropical cyclones according to ground- based GPS network data. Geomagn. Aeron. 2012, 52, 533-545. [CrossRef]

13. Karpov, I.V.; Borchevkina, O.P.; Dadashev, R.Z.; Ilminskaya, A.V. Influence of meteorological storms on ionospheric parameters in the Baltic region in 2010. Solar-Terr. Phys. 2016, 2, 77-81. [CrossRef]

14. Depuev, V.H.; Depueva, A.H. Reaction of the critical frequency of the F2 layer to a sharp depletion in atmospheric pressure. Geomagn. Aeron. 2010, 50, 804-813. [CrossRef]

15. Karpov, I.V.; Borchevkina, O.P.; Karpov, M.I. Local and regional ionospheric disturbances during meteorological disturbances. Geomagn. Aeron. 2019, 59, 458-466. [CrossRef]

16. Karpov, I.V.; Karpov, M.I.; Borchevkina, O.P.; Yakimova, G.A.; Koren'kova, N.A. Spatial and temporal variations of the ionosphere during meteorological disturbances in December 2010. Russ. J. Phys. Chem. B 2019, 13, 714-719. [CrossRef]

17. Astafyeva, E.; Zakharenkova, I.; Förster, M. Ionospheric response to the 2015 St. Patrick's Day storm: A global multi-instrumental overview. J. Geophys. Res. Space Phys. 2015, 120, 9023-9037. [CrossRef]

18. Perevalova, N.P.; Afraimovich, E.L.; Voeykov, S.V.; Zhivetiev, I.V. Parameters of large-scale TEC disturbances during the strong magnetic storm on 29 October 2003. J. Geophys. Res. Space Phys. 2008, 113, A00A13. [CrossRef]

19. Qian, L.; Burns, A.G.; Chamberlin, P.C.; Solomon, S.C. Variability of thermosphere and ionosphere responses to solar flares. J. Geophys. Res. Space Phys. 2011, 116, A10309. [CrossRef]

20. Qian, L.; Wang, W.; Burns, A.G.; Chamberlin, P.C.; Coster, A.; Zhang, S.-R.; Solomon, S.C. Solar Flare and Geomagnetic Storm Effects on the Thermosphere and Ionosphere During 6-11 September 2017. J. Geophys. Res. Space Phys. 2019, 124, 2298-2311. [CrossRef]

21. Rycroft, M.J.; Harrison, R.G.; Nicoll, K.A.; Mareev, E.A. An overview of earth's global electric circuit and atmospheric conductivity. Space Sci. Rev. 2008, 137, 83-105. [CrossRef]

22. Rycroft, M.J.; Harrison, R.G. Electromagnetic atmosphere-plasma coupling: The global atmospheric electric circuit. Space Sci. Rev. 2012, 168, 363-384. [CrossRef]

23. Laštovička, J. Forcing of the ionosphere by waves from below. J. Atmos. Sol.-Terr. Phys. 2006, 68, 479-497. [CrossRef]

24. Blanc, E.; Farges, T.; Pichon, A.; Heinrich, P. Ten year observations of gravity waves from thunderstorms in western Africa. J. Geophys. Res. Atmos. 2014, 119, 6409-6418. [CrossRef]

25. Yiğit, E.; Medvedev, A.S. Influence of parameterized small-scale gravity waves on the migrating diurnal tide in Earth's thermosphere. J. Geophys. Res. Space Phys. 2017, 122, 4846-4864. [CrossRef]

26. Yigit, E.; Koucká Knížová, P.; Georgieva, K.; Ward, W. A review of vertical coupling in the Atmosphere-Ionosphere system: Effects of waves, sudden stratospheric warmings, space weather, and of solar activity. J. Atmos. Sol.-Terr. Phys. 2016, 141, 1-12. [CrossRef]

27. Yamazaki, Y.; Richmond, A.D. A theory of ionospheric response to upward-propagating tides: Electrodynamic effects and tidal mixing effects. J. Geophys. Res. Space Phys. 2013, 118, 5891-5905. [CrossRef] 
28. Cai, X.; Yuan, T.; Eccles, J.V.; Pedatella, N.M.; Xi, X.; Ban, C.; Liu, A.Z. A numerical investigation on the variation of sodium ion and observed thermospheric sodium layer at Cerro Pachón, Chile during equinox. J. Geophys. Res. Space Phys. 2019, 124, 10395-10414. [CrossRef]

29. Oliver, W.L.; Otsuka, Y.; Sato, M.; Takami, T.; Fukao, S. A climatology of F region gravity wave propagation over the middle and upper atmosphere radar. J. Geophys. Res. 1997, 102, 14499-14512. [CrossRef]

30. Xu, S.; Yue, J.; Xue, X.; Vadas, S.L.; Miller, S.D.; Azeem, I.; Straka, W.; Hoffmann, L.; Zhang, S. Dynamical Coupling Between Hurricane Matthew and the Middle to Upper Atmosphere via Gravity Waves. J. Geophys. Res. Space Phys. 2019, 124, 3589-3608. [CrossRef]

31. Djuth, F.T.; Sulzer, M.P.; Gonzales, S.A.; Mathews, J.D.; Elder, J.H.; Walterscheid, R.L. A continuum of gravity waves in the Arecibo thermosphere? Geophys. Res. Lett. 2004, 31, L16801. [CrossRef]

32. Fritts, D.C.; Vadas, S.L.; Wan, K.; Werne, J.A. Mean and variable forcing of the middle atmosphere by gravity waves. J. Atmos. Sol.-Terr. Phys. 2006, 68, 247-265. [CrossRef]

33. Fritts, D.C.; Alexander, M.J. Gravity wave dynamics and effects in the middle atmosphere. Rev. Geophys. 2003, 41, 1-64. [CrossRef]

34. Plougonven, R.; Zhang, F. Internal gravity waves from atmospheric jets and fronts. Rev. Geophys. 2014, 52, 33-76. [CrossRef]

35. Plougonven, R.; Snyder, C. Inertial Gravity waves spontaneously generated by jets and fronts. Part I: Different baroclinic life cycles. J. Atmos. Sci. 2007, 64, 2502-2520. [CrossRef]

36. Gavrilov, N.M.; Koval, A.V. Parameterization of mesoscale stationary orographic wave forcing for use in numerical models of atmospheric dynamics. Izv. Atmos. Ocean. Phys. 2013, 49, 244-251. [CrossRef]

37. Gavrilov, N.M.; Koval, A.V.; Pogoreltsev, A.I.; Savenkova, E.N. Numerical modeling of inhomogeneous orographic wave influence on planetary waves in the middle atmosphere. Adv. Space Res. 2013, 51, 2145-2154. [CrossRef]

38. Astafyeva, E. Ionospheric Detection of Natural Hazards. Rev. Geophys. 2019, 57, 1265-1288. [CrossRef]

39. Klimenko, M.V.; Klimenko, V.V.; Karpov, I.V.; Zakharenkova, I. Simulation of Seismo-Ionospheric effects initiated by internal gravity wave. Russ. J. Phys. Chem. B. 2011, 5, 393-401. [CrossRef]

40. Shalimov, S.; Rozhnoi, A.; Solov'eva, M.; Ol'shanskaya, E. Impact of earthquakes and tsunamis on the ionosphere. Izv. Phys. Solid Earth 2019, 55, 168-181. [CrossRef]

41. Jakowski, N.; Stankov, S.M.; Wilken, V.; Borries, C.; Altadill, D.; Chum, J.; Buresova, D.; Boska, J.; Sauli, P.; Hruska, F.; et al. Ionospheric behavior over Europe during the solar eclipse of 3 October 2005. J. Atmos. Sol.-Terr. Phys. 2008, 70, 836-853. [CrossRef]

42. Altadill, D.; Sole, J.G.; Apostolov, E.M. Vertical structure of a gravity wave like oscillation in the ionosphere generated by the solar eclipse. J. Geophys. Res. 2001, 106, 21419-21428. [CrossRef]

43. Jones, T.B.; Wright, D.M.; Milner, J.; Yeoman, T.K.; Reid, T.; Chapman, P.J.; Senior, A. The detection of atmospheric waves produced by the total solar eclipse of 11 August 1999. J. Atmos. Sol.-Terr. Phys. 2004, 66, 363-374. [CrossRef]

44. Kumar, K.V.; Ajeet, K.M.; Kumar, S.; Singh, R. 22 July 2009 Total Solar Eclipse induced gravity waves in ionosphere as inferred from GPS observations over EIA. Adv. Space Res. 2016, 58, 1755-1762. [CrossRef]

45. Rybnov, Y.S.; Soloviev, S.P. Synchronous variations in the atmospheric pressure and electric field during the passage of the solar terminator. Geomagn. Aeron. 2019, 59, 234-241. [CrossRef]

46. Koucká Knížová, P.; Podolská, K.; Potužníková, K.; Kouba, D.; Mošna, Z.; Boška, J.; Kozubek, M. Evidence of vertical coupling: Meteorological 2018 storm related effects observed on 23 September up to the ionosphere. Ann. Geophys. 2020, 38, 73-93. [CrossRef]

47. Azeem, I.; Barlage, M. Atmosphere-ionosphere coupling from convectively generated gravity waves. Adv. Space Res. 2018, 61, 1931-1941. [CrossRef]

48. Šindelářová, T.; Burešová, D.; Chum, J. Observations of acoustic-gravity waves in the ionosphere generated by severe tropospheric weather. Stud. Geophys. Geod. 2009, 53, 403-418. [CrossRef]

49. Kazimirovsky, E.S. Coupling from below as a source of ionospheric variability: A review. Ann. Geophys. 2002, 45, 1-29. [CrossRef]

50. Koucká Knížová, P.; Mošna, Z.; Kouba, D.; Potužníková, K.; Boška, J. Influence of meteorological systems on the ionosphere over Europe. J. Atmos. Sol.-Terr. Phys. 2015, 136, 244-250. [CrossRef]

51. Rozhnoi, A.; Solovieva, M.; Levin, B.; Hayakawa, M.; Fedun, V. Meteorological effects in the lower ionosphere as based on VLF/LF signal observations. Nat. Hazards Earth Syst. Sci. 2014, 14, 2671-2679. [CrossRef] 
52. Balachandran, N.K. Gravity waves from thunderstorms. Mon. Weather Rev. 1980, 108, 804-816. [CrossRef]

53. Medvedev, A.S.; Gavrilov, N.M. The nonlinear mechanism of gravity wave generation by meteorological motions in the atmosphere. J. Atmos. Sol.-Terr. Phys. 1995, 57, 1221-1231. [CrossRef]

54. Azeem, I.; Yue, J.; Hoffmann, L.; Miller, S.D.; Straka, W.C., III; Crowley, G. Multisensor profiling of a concentric gravity wave event propagating from the troposphere to the ionosphere. Geophys. Res. Lett. 2015, 42, 7874-7880. [CrossRef]

55. Li, W.; Yue, J.; Wu, S.; Yang, Y.; Li, Z.; Bi, J.; Zhang, K. Ionospheric responses to typhoons in Australia during 2005-2014 using GNSS and FORMOSAT-3/COSMIC measurements. GPS Solut. 2018, 22, 61. [CrossRef]

56. Grigor'ev, G.I. Acoustic-gravity waves in the earth's atmosphere (review). Radiophys. Quantum Electron. 1999, 42, 3-25. [CrossRef]

57. Nekrasov, A.K.; Shalimov, S.L.; Shukla, P.K.; Stenflo, L. Nonlinear disturbances in the ionosphere due to acoustic gravity waves. J. Atmos. Sol.-Terr. Phys. 1995, 57, 737-741. [CrossRef]

58. Yigit, E.; Medvedev, A.S. Internal wave coupling processes in Earth's atmosphere. Adv. Space Res. 2015, 55, 983-1003. [CrossRef]

59. Snively, J.B.; Pasko, V.B. Breaking of thunderstorm-generated gravity waves as a source of short-period ducted waves at mesopause altitudes. Geophys. Res. Lett. 2003, 30, 2254-2257. [CrossRef]

60. Schubert, G.; Hickey, M.P.; Walterscheid, R.L. Physical processes in acoustic wave heating of the thermosphere. J. Geophys. Res. 2005, 110, D07106. [CrossRef]

61. Karpov, I.; Kshevetskii, S. Numerical study of heating the upper atmosphere by acoustic-gravity waves from a local source on the Earth's surface and influence of this heating on the wave propagation conditions. J. Atmos. Sol.-Terr. Phys. 2017, 164, 89-96. [CrossRef]

62. Qian, L.; Solomon, S.C.; Kane, T.J. Seasonal variation of thermospheric density and composition. J. Geophys. Res. 2009, 114, A01312. [CrossRef]

63. Akmaev, R.A. Simulation of large-scale dynamics in the mesosphere and lower thermosphere with the Doppler-spread parameterization of gravity waves 1. Implementation and zonal mean climatologies. J. Geophys. Res. 2001, 106, 1193-1204. [CrossRef]

64. Akmaev, R.A. Simulation of large-scale dynamics in the mesosphere and lower thermosphere with the Doppler-spread parameterization of gravity waves 2. Eddy mixing and the diurnal tide. J. Geophys. Res. 2001, 106, 1205-1213. [CrossRef]

65. Karpov, I.V.; Vasiliev, P.A. Ionospheric disturbances due to the influence of localized thermospheric sources. Geomagn. Aeron. 2020, 60, 477-482. [CrossRef]

66. Available online: https://rp5.ru (accessed on 16 September 2019).

67. Karpov, I.V.; Kshevetsky, S.P.; Borchevkina, O.P.; Radievsky, A.V.; Karpov, A.I. Disturbances of the upper atmosphere and ionosphere caused by acoustic-gravity wave sources in the lower atmosphere. Russ. J. Phys. Chem. B 2016, 10, 127-132. [CrossRef]

68. Karpov, I.V.; Borchevkina, O.P.; Vasilev, P.A. Simulation of ionospheric effects induced by meteorological storms. Russ. J. Phys. Chem. B 2020, 14, 362-366. [CrossRef]

69. Liu, J.; Wang, W.; Burns, A.; Solomon, S.C.; Zhang, S.; Zhang, Y.; Huang, C. Relative importance of horizontal and vertical transports to the formation of ionospheric storm-enhanced density and polar tongue of ionization. J. Geophys. Res. Space Phys. 2016, 121, 8121-8133. [CrossRef]

70. Cai, X.; Burns, A.G.; Wang, W.; Coster, A.; Qian, L.; Liu, J.; Solomon, S.C.; Eastes, R.W.; Daniell, R.E.; McClintock, W.E. Comparison of GOLD nighttime measurements with total electron content: Preliminary results. J. Geophys. Res. Space Phys. 2020, 125, e2019JA027767. [CrossRef]

71. Mathews, J.D. Sporadic E: Current views and recent progress. J. Atmos. Sol.-Terr. Phys. 1998, 60, 413-435. [CrossRef]

72. Haldoupis, C. Midlatitude sporadic E. A typical paradigm of atmosphere-ionosphere coupling. Space Sci. Rev. 2012, 168, 441-461. [CrossRef]

73. Yuan, T.; Wang, J.; Cai, X.; Sojka, J.; Rice, D.; Oberheide, J.; Criddle, N. Investigation of the seasonal and local time variations of the high-altitude sporadic $\mathrm{Na}$ layer $\left(\mathrm{Na}_{\mathrm{s}}\right)$ formation and the associated midlatitude descending E layer (Es) in lower E region. J. Geophys. Res. Space Phys. 2014, 119, 5985-5999. [CrossRef]

74. Cai, X.; Yuan, T.; Eccles, J.V.; Raizada, S. Investigation on the distinct nocturnal secondary sodium layer behavior above $95 \mathrm{~km}$ in winter and summer over Logan, UT $\left(41.7^{\circ} \mathrm{N}, 112^{\circ} \mathrm{W}\right)$ and Arecibo Observatory, PR

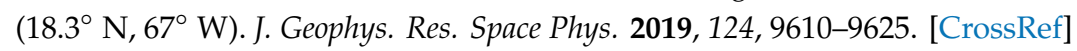


75. Parkinson, M.L.; Dyson, P.L. Measurements of mid-latitude E-region, sporadic-E, and TID-related drifts using HF Doppler-sorted interferometry. J. Atmos. Sol.-Terr. Phys. 1998, 60, 509-522. [CrossRef]

76. Barta, V.; Haldoupis, C.; Sátori, G.; Buresova, D.; Chum, J.; Pozoga, M.; Berényi, K.A.; Bór, J.; Popek, M.; Kis, Á.; et al. Searching for effects caused by thunderstorms in midlatitude sporadic E layers. J. Atmos. Sol.-Terr. Phys. 2017, 161, 150-159. [CrossRef]

77. Fukao, S.; Yamamoto, M.; Tsunoda, R.T.; Hayakawa, H.; Mukai, T. The SEEK (Sporadic-E Experiment over Kyushu) Campaign. Geophys. Res. Lett. 1998, 25, 1761-1764. [CrossRef]

78. Bourdillon, A.; Lefur, E.; Haldoupis, C.; Le Roux, Y.; Menard, J.; Delloue, J. Decameter mid-latitude sporadic-E irregularities in relation with gravity waves. Ann. Geophys. 1997, 15, 925-934. [CrossRef]

79. Scotto, C. Sporadic-E layer and meteorological activity. Ann. Geophys. 1995, 38, 21-24. [CrossRef]

80. Pilipenko, S.G.; Kozak, L.V. Wind shifts in the Earth's atmosphere over powerful hurricanes. Space Sci. Technol. 2012, 18, 43-50. [CrossRef]

81. Liperovsky, V.A.; Pokhotelov, E.V.; Liperovskaya, E.V.; Parrot, M.; Meister, C.-V.; Alimov, O.A. Modification of sporadic E-layers caused by seismic activity. Surv. Geophys. 2000, 21, 449-486. [CrossRef]

82. Gavrilov, N.M.; Kshevetskii, S.P. Numerical modeling of propagation of breaking nonlinear acoustic-gravity waves from the lower to the upper atmosphere. Adv. Space Res. 2013, 51, 1168-1174. [CrossRef]

83. Karpov, I.V.; Kshevetskii, S.P. Formation of large-scale disturbances in the upper atmosphere caused by acoustic gravity wave sources on the Earth's surface. Geomagn. Aeron. 2014, 54, 513-522. [CrossRef]

84. Petrukhin, N.S.; Pelinovsky, E.N.; Batsyna, E.K. Reflectionless propagation of acoustic waves through the Earth's atmosphere. JETP Lett. 2011, 93, 564-567. [CrossRef]

85. Drobzheva, Y.V.; Krasnov, V.M. Acoustic energy transfer to the upper atmosphere from surface chemical and underground nuclear explosions. J. Atmos. Sol.-Terr. Phys. 2006, 68, 578-585. [CrossRef]

86. Drobyazko, I.N.; Gavrilov, N.M. Wave energy and momentum fluxes coming to the middle and upper atmosphere from tropospheric mesoscale turbulence. Phys. Chem. Earth Part C 2001, 26, 449-452. [CrossRef]

87. Heale, C.J.; Snively, J.B. Gravity wave propagation through a vertically and horizontally inhomogeneous background wind. J. Geophys. Res. Atmos. 2015, 120, 5931-5950. [CrossRef]

88. Yuan, T.; Heale, C.J.; Snively, J.B.; Cai, X.; Pautet, P.-D.; Fish, C.; Zhao, Y.; Taylor, M.J.; Pendleton, W.R., Jr.; Wickwar, V.; et al. Evidence of dispersion and refraction of a spectrally broad gravity wave packet in the mesopause region observed by the Na lidar and Mesospheric Temperature Mapper above Logan, Utah. J. Geophys. Res. Atmos. 2016, 121, 579-594. [CrossRef]

89. Astafyeva, E.I.; Afraimovich, E.L.; Voeykov, S.V. Generation of secondary waves due to intensive large-scale AGW traveling. Adv. Space Res. 2008, 41, 1459-1462. [CrossRef]

90. Baran, L.W.; Shagimuratov, I.I.; Tepenitzina, N.J. The Use of GPS for Ionospheric Studies. Artif. Satell. J. Planet. Geod. 1997, 32, 49-60.

91. Hersbach, H.; Dee, D. ERA-5 reanalysis is in production. ECMWF Newsl. 2016, 147, 7.

92. Šauli, P.; Boška, J. Tropospheric events and possible related gravity wave activity effects on the ionosphere. J. Atmos. Sol.-Terr. Phys. 2001, 63, 945-950. [CrossRef]

93. Boška, J.; Šauli, P. Observations of gravity waves of meteorological origin in the F-Region. Phys. Chem. Earth Part C 2001, 26, 425-428. [CrossRef]

94. Šindelářová, T.; Burešová, D.; Chum, J.; Hruska, F. Doppler observations of infrasonic waves of meteorological origin at ionospheric heights. Adv. Space Res. 2009, 43, 1644-1651. [CrossRef]

95. Hickey, M.P.; Walterscheid, R.L.; Schubert, G. Gravity wave heating and cooling of the thermosphere: Sensible heat flux and viscous flux of kinetic energy. J. Geophys. Res. Atmos. 2011, 116, A12326. [CrossRef]

96. Hickey, M.P.; Schubert, G.; Walterscheid, R.L. Acoustic wave heating of the thermosphere. J. Geophys. Res. Space Phys. 2001, 106, 21543-21548. [CrossRef]

(C) 2020 by the authors. Licensee MDPI, Basel, Switzerland. This article is an open access article distributed under the terms and conditions of the Creative Commons Attribution (CC BY) license (http://creativecommons.org/licenses/by/4.0/). 